\title{
Formulation of Brown Rice Flour Cookies Combination with Bay Leaf Extract (Syzygium Polyanthum) As a Functional Food
}

\author{
FORMULASI COOKIES TEPUNG BERAS MERAH KOMBINASI EKSTRAK DAUN \\ SALAM (Syzigium plytanthum) SEBAGAI PANGAN FUNGSIONAL
}

\author{
Cantika Zaddana ${ }^{1 *}$, Almasyhuri ${ }^{1}$, Dena Alfitri ${ }^{1}$, Sara Nurmala1, Fitria Dewi \\ Sulistiyono ${ }^{1}$ \\ 1 Pharmacy Study Program, Faculty of Mathematics and Natural Sciences, Pakuan University \\ * Email corresponding author: cantika.zaddana@unpak.ac.id
}

\begin{abstract}
Functional food is a processed food that contains more than one component which based on scientific studies has benefits for the health of the body. Functional foods can be classified into several types based on the food source and the processing method. This study aims to determine the proximate composition, fiber and flavonoid contents, and the effect of the varying concentrations of the bay leaf extract on the cookies. Three formulas of bay leaf extract were made with different concentrations. The formula I use $3.0 \%$, formula II uses $2.5 \%$, and formula III uses $2 \%$. The results of the hedonic test analysis showed that the best formula was formula III with a concentration of $2 \%$ bay leaf extract. These results indicate that the concentration of the bay leaf extract affects the taste and aroma of the cookies, even though it does not affect the color and texture. By using formula III, proximate tests were also carried out on these cookies to determine water content, ash content, protein content, fat content, and carbohydrate content. The proximate test results showed that the cookies met the quality requirements of cookies set by SNI 2973-2011. In formula III cookies, the content of flavonoids was 1.4278\%, and food fiber was $6.04 \%$.
\end{abstract}

Keywords: Cookies, Brown Rice Flour, Bay Leaves, Flavonoid

\section{INTRODUCTION}

Bay leaves (Syzygium polyanthum) is a spice leaf that is often used in Indonesian cuisine, in addition to cooking spices, bay leaves can also be used as an antihypertensive herb. According to Agoes (2010), bay leaves have been studied to see antihypertensive effects in rats. The results of experiments show that rats given bay leaf extract can show a decrease in systole and diastole pressure. Cookies combined with bay leaves can be effective as anti-hypertensive. Hypertension is a condition of increased blood pressure above normal, the limit of blood pressure can be considered normal if the blood pressure is $140 / 90 \mathrm{mmHg}$, and it can be declared hypertension if the blood pressure is $>160 / 95 \mathrm{mmHg}$. These restrictions do not distinguish gender or age (18).

There are three chemicals contained in bay leaves, namely tannins, flavonoids, and essential oils. Tannins in bay leaves can relax arterial muscles and can lower blood pressure for people with hypertension. Flavonoids are ace inhibitors that can inhibit ACE activity with the formation of angiotensin II can be limited to prevent 
hypertension. Essential oils can be useful as a fragrance or flavoring in foods to calm our minds and reduce hormone stress (1). The water decoction of bay leaves can be used as an alternative as a drug in hypertension in the community because it has properties that can decrease systolic or diastolic blood pressure (8).

Brown rice (Oryza nivara) is usually consumed without any processing process, other than just milled into broken rice husk. The husk within brown rice is rich in essential fats, fiber, and contains benefits that prevent various digestive tract diseases and related to cholesterol. In brown rice, there is an anthocyanin pigment which is a source of dye from brown rice that acts as an antioxidant and has properties to prevent diseases such as coronary heart, hypertension, cancer, and diabetes (16).

Brown rice flour is used as a primary ingredient in making cookies, according to Suardi (2005), there is a red pigment in the skin layer of brown rice that makes the appearance of cookies more attractive. Brigitta et al. (2017) also said cookies that use brown rice flour could be accepted by panelists because the color on cookies becomes increasingly attractive.

The creation of formula cookies in this study was adapted from Juwita (2012). Previous research consisted of 4 formulas, they are $0 \%, 25 \%, 50 \%, 75 \%$, and $100 \%$. The best cookie formula from the previous research result is in the comparison of brown rice flour at a substitution level of $75 \%$. Therefore, this study uses a $75 \%$ brown rice flour formula with a $25 \%$ wheat flour ratio.

Brown rice flour cookies combined with bay leaf extract are made to cover the bitter taste of bay leaves so that people can consume bay leaves as anti-hypertensive easily without having to feel a bad taste in bay leaves consumed without undergoing any processing. Based on Hairunisa research (2014), the level of adherence to taking drugs in the elderly is getting lower, therefore bay leaves are modified into cookies because the taste of cookies that have been combined is better than consuming bay leaves directly.

\section{METHODS}

This research was conducted from July to September 2020 at the Pharmaceutical Laboratory of the Faculty of Mathematics and Natural Sciences, Pakuan University, Bogor, and Saraswanti Indo Genetech Laboratory.

\section{Tools and Materials}

The tools used are glassware, analytical scales, oven (Memmert $®$ ), krus, furnance (ney®), sieve mash 80, sieve mash 40, basin, cup, batis fabric, cookie mold, pan, water handler, blander (Philips®), rotary evaporator, UV-VIS spectrophotometer (Optizen $®)$, Soxhlet, Kjeldahl flask, chemical glass tools. The ingredients needed are bay leaf extract, brown rice flour, and other additives such as wheat flour, refined sugar, butter, egg yolk, vanilla, salt, baking powder. The chemicals used for the analysis are $\alpha$ amylase, aquadest, protase, amylo-glucosidase, ethanol $78 \%$, ethanol 95\%, HCL, Mg Zn powder, aluminum chloride, sodium acetate, concentrated hydrochloric acid, quercetin, hexane, concentrated sulfuric acid, and acetone.

\section{Procedure of Bay Leaf Extract}


Extraction using the method of infundation with bay leaf powder 500grams and water solvent $5000 \mathrm{~mL}$ heated over the water handler for 15 minutes, starting from the temperature reaches $90{ }^{\circ} \mathrm{C}$ occasionally stirred. Filtered with batis fabric. The liquid extract obtained is compressed with rotary after being inserted into the water bath to get a thick extract.

\section{Procedure of Brown Rice Flour}

The process of making brown rice flour is washed with clean water, then soaked for 12 hours, drained or in the air until the rice is dry, after that it is milled and then after going through the brown rice flour milling process it is then sifted through an 80 mesh sieve (20).

\section{Qualitative Flavonoid Test}

The extract is weighed as much as 0.5 grams, then added 2-3 drops of ethanol, added mg or Zn powder, and a few drops of concentrated hydrochloric acid. If the color is formed red or orange, it indicates the presence of flavonoid compounds, and if formed orange-yellow color then shows flavon, kalkon, and auron (11).

\section{Cookie Formulation}

The dose in the preliminary test of cookies with an extract amount of 14.8 grams made the cookies taste bitter so that each formula used a concentration of bay leaf extract of $50 \%$ of the initial dose. Making brown rice flour cookies with a combination of bay leaf extract made three formulas, and each formula was made three times and get 300 grams of cookie dough to obtain 60 pieces of cookies in every formula. The formula used in this study was modified from the research of Juwita (2012).

Table 1. Formulation of Brown Rice Flour Cookies Combination of Bay Leaf Extract.

\begin{tabular}{clll}
\hline Material & F1 & F2 & F3 \\
\hline Bay Leaf & 3,0 & 2,5 & 2 \\
Extract & & & \\
Brown Rice & 38,9 & 39,4 & 39,9 \\
Flour & 13,0 & 13,0 & 13,0 \\
Flour & 23,6 & 23,6 & 23,6 \\
Butter & 14,5 & 14,5 & 14,5 \\
Refined Sugar & 0,4 & 0,4 & 0,4 \\
Salt & 0,4 & 0,4 & 0,4 \\
Vanilla Paste & 5,5 & 5,5 & 5,5 \\
Yolk & 0,7 & 0,7 & 0,7 \\
Baking & 100 & 100 & 100 \\
Powder & & &
\end{tabular}




\section{Cookie Production}

Firstly, the tools and ingredients are prepared, then weighing on the ingredients in accordance with the formula on the table. Prepare a basin to make the dough and stir the sugar, butter and salt, egg yolks, and vanilla paste until evenly distributed. Mix brown rice flour, wheat flour, bay leaf extract, and baking powder. Stir the dough until dull, after that mold the cookies (5grams) and bake using the oven.

\section{Hedonic Test}

According to Setyaningsih et al (2010), the hedonic test was carried out which aims to determine the opinion of the panelists on cookies more specifically on the level of preference of the panelists. On the finished cookies, then conducted a hedonic test with 30 panelists with a requirement of 18 years - 25 years to assess the cookies' taste, aroma, and color. Previously panelists did not consume foods or drinks that could affect the assessment. The panelists are given questionnaire paper, interval to taste formula 1 with the next formula that is for 1 minute, and panelists are expected to rinse their mouth and drink water first before tasting the next formula. Hedonic test parameters include the taste, aroma, texture, and color of cookies. To see the panelists' preferred level by rating: strongly dislike (1), dislike (2), quite like (3), like (4), very much like (5).

The results of the hedonic test data will be analyzed to determine the best formula using SPSS. The best test results will be conducted in several tests: Test of proximate levels (water content test, ash content, protein levels, fat content, and carbohydrate levels), tests of dietary fiber cookies, and tests on the determination of flavonoid levels in cookies.

\section{Proximate Test}

\section{Water Analysis Test}

The water content test aims to provide a limit on the amount of water content contained in the material. The method used in testing the water content is by using the gravimetric method. The sample is weighed 1-2 grams, then the empty crucible is heated for 10 minutes and then weighed, then the sample is put into a crucible that has been measured. The crucible containing the sample was dried at $105^{\circ} \mathrm{C}$ after which it was cooled and weighed. Drying was continued and reweighed after a distance of 1 hour until a constant weight was obtained. The constant requirement is if the difference between 2 consecutive weighing is not more than 0.0025 gram or $0.25 \%$ (9).

\section{Ash Analysis Test}

The ash content test aims to provide an overview of the mineral content contained from the beginning of the process until the formation of simplicia. The sample is weighed as much as 2-3 grams, then put the sample into a silicate crucible that has been incandescent and measured. The sample is incandescent at a temperature of $\pm 6000 \mathrm{C}$ slowly until the charcoal runs out, after that it is cooled and weighed to a constant weight of \pm 0.25 . If the charcoal cannot be lost in this way, hot water can be added, then stirred and filtered. The sample is inserted into the exchange rate then evaporated and ignited until the weight is constant (9). 


\section{Fat Analysis Test}

Testing the fat content using the Soxhlet method. A total of 2 grams of the mashed sample, dried in an oven at a temperature of more than $80^{\circ} \mathrm{C}$ for \pm 1 hour, then the sample was wrapped in filter paper, then put into a Soxhlet extraction tube which had been connected to a fat flask containing boiling stones that had been dried and known weight. Samples were extracted with hexane for \pm 6 hours. After that, the fat extract was then dried in a drying oven at $150^{\circ} \mathrm{C}$ for 30 minutes. Then cooled and weighed (drying is repeated until the weight remains) (2).

\section{Protein Analysis Test}

The concentration measurement was carried out using the Foss Tecator Kjeldahl method. A number of samples were carefully weighed 1 gram of sample (for high protein 0.3-0.5 grams) into a Kjeldahl tube and added with $15.00 \mathrm{~g}$ of K2SO4, $1 \mathrm{~mL}$ of CuSO4 catalyst solution, 1 gram of selen mixture, 8 to 10 boiling stones and $25 \mathrm{~mL}$ concentrated H2SO4. Heat the mixture on an electric heater until it boils and the solution becomes clear greenish, do it in a fume hood. Allow to cool then dilute with sufficient distilled water, then add $75 \mathrm{~mL}$ of $30 \% \mathrm{NaOH}$ solution (check with PP indicator until the solution becomes wet), distilled for 10 minutes or until the distillate solution reaches $15 \mathrm{~mL}$. Rinse the tip of the cooler with distilled water, then titrate the distillate mixture solution with $0.05 \mathrm{~N}$ HCL solution and determine the blank. (5).

\section{Carbohydrate Analysis Test}

The formula can determine determination of carbohydrate content by the method by difference carbohydrate content:

$$
\% \text { Carbohydrates }=100 \%-(\text { water }+ \text { ash }+ \text { fat }+ \text { protein })
$$

\section{Fiber Analaysis Test}

Weighed carefully (duplo) $0.5 \pm 0.005 \mathrm{~g}$ of sample, added $40 \mathrm{~mL}$ of MES-TRIS (buffer $\mathrm{pH}$ 8.2), then stirred until homogeneous. Added $50 \mu \mathrm{l} \alpha$-Amylase, stored in a water bath 95$100{ }^{\circ} \mathrm{C}$ for 35 minutes. Then cooled to $60^{\circ} \mathrm{C}$, rinsed the walls of the beaker with $1-\mathrm{mL}$ of water. $100 \mathrm{l}$ of protease was added, then incubated at $60^{\circ} \mathrm{C}$ for 30 minutes. $0.561 \mathrm{~N} \mathrm{HCl}$ was added to $\mathrm{pH} 4.5$ (4.1-4.6) and $200 \mathrm{l}$ of amyloglucosidase was added, incubated at 60 ${ }^{\circ} \mathrm{C}$ for 30 minutes. Precipitated with $225 \mathrm{~mL}$ of $95 \%$ ethanol at $60^{\circ} \mathrm{C}$, allowed to precipitate for 1 hour at room temperature. Filtered with odorless filter paper Number 42 which has known weight. Washed with $15 \mathrm{~mL}$ of $78 \%$ ethanol, $15 \mathrm{~mL}$ of $95 \%$ ethanol and $15 \mathrm{~mL}$ of acetone 2 times. Dry in a vacuum oven at $70^{\circ} \mathrm{C}$ or at a temperature of $105^{\circ} \mathrm{C}$. (3).

\section{Determination of Total Flavonoid Levels (Chang, et all. 2002)}

A total of $50 \mathrm{mg}$ was weighed and then dissolved with methanol to $50 \mathrm{~mL}$. Pipette $10 \mathrm{~mL}$ of the extract solution into a $50 \mathrm{~mL}$ volumetric flask and then add approximately $20 \mathrm{~mL}$ of distilled water, $1 \mathrm{~mL}$ of $10 \%$ aluminum chloride, $1 \mathrm{~mL}$ of $1 \mathrm{M}$ sodium acetate and distilled water to the limit. Shake until homogeneous and left for the optimum time, the absorption is measured at the maximum wavelength. The resulting absorbance was entered into the regression equation and the quercetin standard curve (Saifudin et al, 2011). 


\section{RESULTS AND DISCUSSION}

Total $1.5 \mathrm{~kg}$ of brown rice produces 956 grams of brown rice flour. The percentage yield of bay leaf simplicia powder obtained was $24.2 \%$. The yield of the bay leaf extract obtained was $12.2 \%$.

The results of organoleptic test of raw material for brown rice flour have a fine powder texture, tasteless, distinctive smell, whitish red in color. Bay leaf simplicia powder is finely textured, has a chelating taste, and has a characteristic aromatic smell. Bay leaf extract in thick blackish brown extract has a characteristic aromatic smell and a chelating taste.

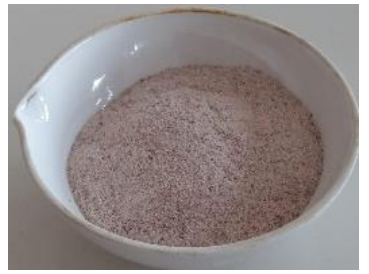

A

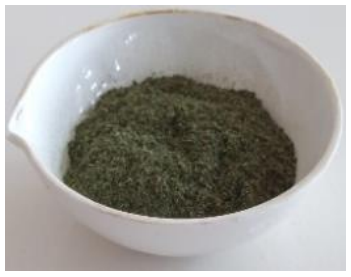

B

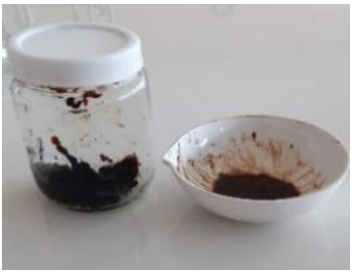

C

Picture 1. Brown Rice Flour (A), Bay Leaf Simplicia Powder (B), Bay Leaf Extract (C)

\section{Qualitative Flavonoid Test}

Bay leaf simplicia powder and bay leaf extract which will be used as raw materials in this study, were tested for qualitative flavonoids to know the presence or absence of flavonoid content in bay leaves.

\section{Hedonic Test Results}

The analysis of variance using Duncan's method shows that for the color and texture parameters in all formulas, there is no significant difference with the values of sig $0.340>$ 0.05 and sig $0.878>0.05$.

Meanwhile, the taste and aroma parameters showed significant differences between FI, FII, and FIII with sig value $0.000<0.05$. Panelists also preferred formula III because in formula III the aroma of bay leaves was weaker than the other formulas, in formula III also The taste of the bay leaf is not chelating, this is because the concentration of the bay leaf extract in formula III is less than the other formulas.

Table 2. Results of Analysis of Variety of Brown Rice Flour Cookies Combination of Bay Leaf Extract

\begin{tabular}{|c|c|c|c|c|c|}
\hline \multirow{2}{*}{ Formula } & \multicolumn{4}{|c|}{ Average } & \multirow{2}{*}{$\begin{array}{l}\text { Average from All } \\
\text { Parameters }\end{array}$} \\
\hline & Color & Taste & Aroma & Texture & \\
\hline I & $3.47^{\mathrm{a}}$ & $2.73^{\mathrm{c}}$ & $2.43^{c}$ & $3.43^{\mathrm{a}}$ & 3,02 \\
\hline II & $3.40^{\mathrm{a}}$ & $2.97^{\mathrm{b}}$ & $3.07^{\mathrm{b}}$ & $3.50^{\mathrm{a}}$ & 3,24 \\
\hline III & $3.53^{\mathrm{a}}$ & $3.30^{\mathrm{a}}$ & $3.33^{a}$ & $3.47^{a}$ & 3,41 \\
\hline
\end{tabular}




\section{Cookies Proximate Test Results}

The proximate test on brown rice flour cookies combined with bay leaf extract was carried out on formula III because formula III was the most preferred formula by the panelists.

Table 3. Proximate Test Results on Brown Rice Flour Cookies Combination of Bay Leaf Extract

\begin{tabular}{cccc}
\hline Parameter & Result & SNI 2973-2011 & Description \\
\hline Water & $3,3 \%$ & Max 5\% & Fulfilled the requirement \\
Ash & $1,4 \%$ & Max 1,6\% & Fulfilled the requirement \\
Protein & 7,67 & Min 5\% & Fulfilled the requirement \\
Far & 11,50 & Min 9\% & Fulfilled the requirement \\
Carbo-hydrate & 76,42 & Min 70\% & Fulfilled the requirement \\
\hline
\end{tabular}

The results of the analysis of the water content in cookies were obtained at $3.3 \%$. The results fulfilled the requirements for the water content of cookies because the results were not more than 5\% (5). Determination of these quality requirements aims to prevent microbial growth that can damage the quality of cookies (19). Calculation of water content can be seen in appendix 13.

The ash content was carried out using the gravimetric method. The ash content in the resulting cookies was 1.4\%, which was in the range of requirements according to SNI 29732011 , namely the maximum ash content in cookies was $1.6 \%$.

Testing the fat content in cookies was carried out by the Soxhlet method. The results of the fat content test in the cookies were $11.50 \%$, it fulfilled the requirements for the amount of fat contained in cookies not less than $9 \%(5)$.

According to SNI 2973-2011 the requirement for the amount of protein in cookies is a minimum of $5 \%$, from the results of protein analysis in cookies of $7.67 \%$ indicate that the amount of protein in cookies fulfill the specified quality requirements.

The amount of carbohydrates contained in cookies are $76.42 \%$, it fulfilled the quality requirements of SNI 2973-2011. According to Sugito and Hayati (2006), carbohydrate levels calculated using the by difference method are influenced by other nutritional components, the higher the other nutritional components, the lower the carbohydrate content and vice versa.

The amount of dietary fiber contained in cookies is $6.04 \%$. This means that the fiber content in cookies fulfilled the claim requirements. Based on the BPOM (2011) reference which states that the nutritional content of food fiber sources is not less than $6 \%$. According to Thompson, et al. (2011) states that fiber has a relationship with bile acids, if the fiber is not able to reduce cholesterol levels so that it is unable to bind bile salts, it cannot prevent the absorption of cholesterol in the intestines and results in more cholesterol in the blood resulting in increased cholesterol levels and cause hypertension. 


\section{Recommended Dietary Allowances (RDA) of Cookies}

The serving size of cookies is included in the ready-to-eat snack category, which has a serving size range of 20-40grams (BPOM, 2015). The serving sizes on the market are 30 grams of monde butter cookies, and 25 grams of Oriorio biscuits. Thus, the serving dose of brown rice flour cookies with a combination of bay leaf extract was determined to be 25 grams with a weight of 5 grams for each cookie. The general category's RDA values for macromolecular nutrition are 60 grams of protein, 325 grams of carbohydrates, 67 grams of total fat, and 2150 total energy (BPOM, 2016). The results of the serving size on brown rice flour cookies with a combination of bay leaf extract that can fulfilled the protein content of $1.91 \%$, carbohydrates of $19.10 \%$, and fat content of $11.5 \%$. Thus, brown rice flour cookies combined with bay leaf extract can be used as an alternative functional food that can help to fulfill daily nutritional needs.

Table 4. Results of the Recommended Dietary Allowances (RDA)

\begin{tabular}{ll}
\hline Parameter & Result \\
\hline Protein & $0,383 \mathrm{~g}$ \\
Carbohydrate & $3,821 \mathrm{~g}$ \\
Fat & $0,575 \mathrm{~g}$ \\
\hline
\end{tabular}

\section{Total Flavonoid Level Results}

The maximum wavelength is at a wavelength of $432 \mathrm{~nm}$ with an optimum incubation time of 30 minutes. The standard curve results obtained resulted in a regression value of $y=$ $0.0038 \mathrm{x}+0.0681$ where the $\mathrm{x}$ value indicates the extracted content (ppm), if the extract absorbance value is entered as the $\mathrm{y}$ value, the $\mathrm{x}$ value can be calculated as the content $(\mathrm{ppm})$. This curve also produces a value of $\mathrm{r} 2=0.8237$ where this value shows the closeness of linearity, which is close to 1 , so it can be said that the absorbance is a function whose value is proportional to 1 .

Based on the results obtained, the total flavonoids in the bay leaf extract were $1.5301 \%$. These results showed that the results were not much different from Helpida (2012) research, which stated that the total flavonoid content in the extract was $1.505 \%$. The results of total flavonoids contained in the bay leaf extract cookies amounted to $1.4278 \%$. The total flavonoid content showed that the flavonoid content in the extract was greater than the flavonoid content in the preparation of the cookies, this was because the cookies had added other additives and had also undergone several processes such as roasting so that the flavonoid levels were degraded. Pharmacologic doses of bay leaf extract to rats that have been examined by Agoes (2010) is $0.034 \mathrm{~g} / \mathrm{kg}$ can lower systolic and diastolic blood pressure, the dose conversion Based on the bay leaf extract that one day eat five cookies with the content of the extract per cookies 0,27 gram It can lower systolic and diastolic blood pressure. The protective cardiovascular effects of flavonoids, especially as antihypertensive, have been extensively studied. This compound produces the ability to reduce oxidative stress, inhibit the activity of angiotensin-converting enzyme, increase relaxation of vascular endothelium, regulate cell signaling and gene expression (Granse F., at al. 2016). 


\section{CONCLUSION}

1. The results of the hedonic test of the formula that the panelists most favored were in formula III with a concentration of 2grams bay leaf extract.

2. The test results for the proximate levels of cookies formula III showed that the test fulfilled the quality requirements of cookies according to SNI 2011.

3. Cookies have a high dietary fiber content of $6.04 \%$ and a flavonoid content of $1.4278 \%$.

\section{SUGGESTION}

1. There is a need for stability testing that aims to determine the storage time of cookies.

2. Preclinical testing is needed to find out that formula 3 is a functional food for hypertension.

\section{REFERENCES}

1. Agoes, A. (2010). Tanaman Obat Indonesia Edisi Kedua. Jakarta: Salemba Medika.

2. AOAC. (2005). Official Method of Analysis the Association Official Analytical Chemist. Benyamin Franklin Station. Washington, D.C.

3. AOAC. (2001). Official Methode Of Analysis Of The Association Of Analytical Chemists. Washington D.C.

4. Badan Standar Nasional. (2009). Tepung Terigu Sebagai Bahan Makanan. SNI 3751: 2009.

5. Badan Standarisasi Nasional. (2011). Biskuit. 01-2973-2011, Jakarta: Departemen Perindustrian.

6. Badan Standarisasi Nasional. (2005). Ketentuan Pangan Fungsional. 00.05.52.0685. Jakarta: Badan Pengawasan Obat dan Makanan.

7. Badan Pengawasan Obat dan Makanan. (2011). Pengawasan Klaim Dalam Label Dan Iklan Pangan Olahan. Jakarta.

8. Dafriani, P. (2016). Pengaruh Rebusan Daun Salam (Syzygium polyanthum) Terhadap Tekanan Darah Pasien Hipertensi Disungai Bungkal. Jurnal Medika Saintika. Volume 7 No. 2: 25-34.

9. Ditjen POM. (2000). Parameter Standar Umum Eksstrak Tumbuhan Obat Cetakan Pertama. Jakarta: Departemen Kesehatan Republik Indonesia.

10. Hairunisa, (2014). Hubungan Tingkat Kepatuhan Minum Obat Dan Diet Dengan Tekanan Darah Terkontrol Pada Penderita Hipertensi Lansia di Wilayah Puskesmas Perumnas. Naskah Publikasi. Pontianak: Universitas Tanjungpura Pontianak.

11. Hanani E. (2017). Analisis Fitokimia. Jakarta: EGC.

12. Helpida, V. (2012. Formulasi Granul Efervesen Ekstrak Biji Alpukat Dan Daun Salam Denga Perbedaan) Konsentrasi Asam Dan Basa. Skripsi. Fakultas Matematika Dan Ilmu Pengetahuan Alam Bogor.

13. Juwita, Z. (2012). Formulasi dan Indeks Glikemia Cookies Ganyong. Skripsi. Bogor: Institut Pertanian Bogor.

14. Santika, A. dan Rozakurniati. (2010). Teknik Evaluasi Mutu Beras Ketan dan BerasMerah Pada Beberapa Galur Padi Gogo. Buletin Teknik Pertanian Vol. 15, No. 115 (1):1-5.

15. Setyaningsih D, Apriyantono A, Sari Mp. (2010). Analisi Sensori Untuk Industri Pangan dan Agro. Bogor: Institut Pertanian Bogor.

16. Suardi, D. (2005). Potensi Beras Merah Untuk Peningkatan Mutu Pangan. Jurnal Litbang Pertanian. Volume 24 No. 3: 93-100. 
17. Sugito dan Hayati A. (2006). Penambahan Daging Ikan Gabus (Phicepallus strianus BLKR) dan Aplikasi Pembekuan Pada Pembuatan Pempek Gluten. Jurnal Ilmu-Ilmu Pertanian Indonesia 8(2): 147-151.

18. Udzianti, W, J. (2011). Keperawatan Kardio Vaskular. Jakarta: Salemba Medika

19. Wijaya H, Aprianita N. (2010). Kajian Teknis Standar Nasional Indonesia Biskuit SNI 01-2971-1992.

20. Wijayanti, I. (2015). Eksperimen Pembuatan Kue Sempring Tepung Beras Merah, Skripsi. Semarang: Universitas Negeri Semarang. 